\title{
Doğal Soğutucu Akışkan Kullanımında Gelişmeler
}

\author{
Esra DEMİRCI' ${ }^{\mathbb{D}}$, Mehmet ÖZKAYMAK $^{\mathrm{b}} \mathbb{D}$, Meltem $\mathrm{KOŞAN}^{*}, \mathrm{c} \mathbb{D}$, Ahmet Eren AKKOÇ ${ }^{\mathrm{d}} \mathbb{D}$, \\ Mustafa AKTAŞ ${ }^{\mathrm{e}}$ \\ a Karabük Üniversitesi, Enerji Sistemleri Mühendisliği Bölümü, 78050, KARABÜK, TÜRKİYE \\ ${ }^{b}$ Karabük Üniversitesi, Enerji Sistemleri Mühendisliği Bölümü, 78050, KARABÜK, TÜRKIYE \\ ${ }^{c,{ }^{*}}$ Gazi Üniversitesi Enerji Sistemleri Mühendisliği Bölümü, 06500, ANKARA, TÜRKİYE \\ ${ }^{d}$ Gazi Üniversitesi Enerji Sistemleri Mühendisliği Bölümü, 06500, ANKARA, TÜRKIYYE \\ ${ }^{e}$ Gazi Üniversitesi Enerji Sistemleri Mühendisliği Bölümü, 06500, ANKARA, TÜRKIYYE
}

\section{MAKALE \\ BİLGİSI \\ Alınma: 29.08.2020 \\ Kabul: 01.12.2020

Anahtar Kelimeler:
Enerji verimliliği,
soğutma, soğutucu
akışkanlar, soğutucu
akışkanların çevresel
etkisi
"Sorumlu Yazar:
e-posta:
mltmkosan@gmail.co

$\mathrm{m}$

\section{$\ddot{O Z Z}$}

Günümüzde son zamanlarda, insanoğlu tarafindan enerji sistemlerinin ısıtma ve soğutma amaciyla kullanılan sentetik soğutucu akışkanların yol açtığı hava, su, toprak kirliliği, ozon tabakasının tahribatı ve küresel ısınma gibi çevresel sorunlar yalnızca insan sağlığını tehdit etmeyip tüm canlı ve cansız türlerin yaşamlarını ve geleceğini önemli ölçüde etkilemektedir. Bu çalışmada, çevreye olan zararların minimum seviyeye indirilmesi için sentetik soğutucu akışkanlara alternatif olarak kullanılabilecek doğal soğutucu akışkanlardan (R290, R600, R717, R744 vb.) ve uygulama örneklerinden bahsedilmiștir. Doğal soğutucu akışkanların kullanımı, soğutma sistemi performans katsayısı ve sistemin teknolojik özellikleri açısından yapılan çalışmalar incelenmiştir. Elde edilen bulgular ve çıkarımlar ısıtma ve soğutma sistemi tasarımcılarına enerji verimliliği ve çevre kriterleri anlamında 1 şı tutacaktır.

https://dx.doi.org/10.30855/gmbd.2020.03.02

\section{Developments in Natural Refrigerant Usage}

\section{ARTICLE \\ INFO \\ Received: 29.08 .2020 \\ Accepted: 01.12.2020 \\ Keywords: \\ Energy efficiency, \\ cooling, refrigerants, \\ environmental impact \\ of refrigerants \\ "Corresponding \\ Authors \\ e-mail: \\ mltmkosan@gmail.co}

\begin{abstract}
Recently, environmental problems such as air, water, soil pollution, ozone layer destruction, and global warming caused by synthetic refrigerants used by human beings for heating and cooling of energy systems do not only threaten human health but also significantly affect the lives and future of all living and non-living species. In this study, natural refrigerants (R290, R600, R717, R744 etc.) that can be used as an alternative to synthetic refrigerants and application examples are mentioned in order to minimize environmental damage. Studies conducted in terms of the use of natural refrigerants, cooling system performance coefficient, and technological features of the system have been examined. The findings and inferences obtained will shed light on the heating and cooling system designers in terms of energy efficiency and environmental criteria.
\end{abstract}

https://dx.doi.org/10.30855/gmbd.2020.03.02

Bu makaleye atıf yapmak için: E. Demirci, M. Özkaymak, M. Koşan, A.E. Akkoç ve M. Aktaş, "Doğal Soğutucu Akışkan Kullanımında Gelişmeler," Gazi Mühendislik Bilimleri Dergisi, cilt 6, sayı 3, s. 184-199, Aralık, 2020, doi: https://dx.doi.org/10.30855/gmbd.2020.03.02. 


\section{GİRIŞ (INTRODUCTION)}

Soğutma işlemi bir maddenin veya bir ortamın sıcaklığını çevre sıcaklığının altına düşürmek için ısının çekilmesi işlemidir. Tarihte bilinen ilk yapay soğutma işlemi üzerine çalışmalar 1755 yılında Scotland' da Glasgow Üniversitesi'nden Dr. William Cullen'ın eline sürdüğü eterin çevreden 1s1 alarak buharlaşması sonucu elinin soğuduğunu fark etmesi ile başlamıştır. Soğutma işlemi tarih içerisinde birçok aşamadan geçerek ve gelişerek günümüze kadar gelmiştir. 14 Ağustos 1834 yllında Jacop Perkins Amerika' da ilk buhar sıkıştırmalı soğutma çevriminin patentini almıştır [1]. Buhar sıkıştırmalı soğutma çevrimiyle aynı prensibe sahip olan 1s1 pompası Lord Kelvin tarafindan 1850 yılında soğutma amaçlı kullanılan cihazların ısıtma amaçlı kullanılabileceği fikrini ileri sürmesiyle 1sı pompası uygulamalarına da başlanmıştır. Perkins'den 25 yll sonra ilk absorpsiyonlu soğutma sistemi 1859 'da Fransiz mühendis Ferdinand Carre tarafindan geliştirilmiş ve 1860 yllında patenti alınmıştır [2]. Soğutucu akışkanların tarihsel gelişimi Şekil 1'de özetlenmiştir. Gerek ticari uygulamalarda gerek laboratuvar koşullarında kullanılacak soğutucu akışkanlardan emniyetli ve çevreyle dost olmalarının yanı sıra genel olarak istenilen özellikler [3]; pozitif buharlaşma basıncına sahip olmalıdır, yüksek buharlaşma gizli 1sısına, yoğuşma basıncının düşük değerlere sahip olması ve inert madde özelliğinde olması gerekmektedir. Ayrıca zehirlenme, yanma ve patlama tehlikelerine karşı emniyetli olmalıdır. Sistemde meydana gelebilecek soğutucu akışkan sızıntıları kolayca tespit edilebilmelidir. Ekonomik olmalıdır, yüksek 1sıl iletkenliğe sahip, donma sicaklık derecesinin çok düşük, kritik sıcaklık değerinin ise yüksek değerlere sahip olması, elektriksel olarak yalıtkan özellik göstermesi ve özgül hacmi ile viskozite değerinin düşük olması gerekmektedir.

Isıtma ya da soğutma amaciyla çeşitli çevrimlerde kullanılan soğutucu akışkanlar iki farklı ortam arasında 1S1 alışverişini sağlayan yardımcı bir maddedir. Diğer bir ifadeyle soğutulacak olan maddelerden doğrudan ve/veya dolaylı olarak is1 alarak onları soğutan maddelere soğutucu akışkan denir. Günümüzde birçok soğutucu akışkan aktif olarak kullanılmaktadır. Geçmişten günümüze kadar pek çok soğutucu akışkanın keşfi yapılmıştır. Fakat bir kısmı günümüzde çeşitli nedenlerden dolayı kullanımı yasaklanmış veya işletme şartlarına uyum sağlayacak özelliklerde geliştirilmesi sağlanmıştır [4]. Soğutma endüstrisinde $1 S 1$ çekmek için ilk zamanlarda su, amonyak, hava, karbondioksit gibi doğal akışkanlar kullanılmıştır. 1930 yılına kadar amonyak, klorometan, karbon tetraklorür, izobütan ve propan yaygın olarak kullanılan soğutucu akışkanlardır [5]. Zamanla gelişen soğutma ve kimya endüstrisi ile bu akışkanların yerini yapay olarak elde edilen kimyasal akışkanlar almıştır. 1930 yılında $\mathrm{R} 12\left(\mathrm{CF}_{2} \mathrm{Cl}_{2}\right)$ gazı bulunarak kloroflorokarbonlar (CFC) soğutucu akışkanların temeli atılmıştır. Yeni üretilen bu soğutucu akışkan zehirleyici ve yanıcı olmaması, kararlı bir kimyasal ve 1sıl özelliklerinin iyi olması sebebiyle ne yazık ki atmosfere salınan sızıntılar ve verdiği zararlar tolere edilmiş 1930'lu yıllardan 1990'l yıllara kadar tercih edilen bir soğutucu akışkan olmuştur. 5 y1l sonra 1935 y1lında R22 $\left(\mathrm{CHF}_{2} \mathrm{Cl}\right)$ soğutucu akışkanı bulunarak Hidrokloroflorokarbon (HCFC) kökenli akışkanlar geliştirilmiş̧ir. Önceleri yaygın kullanılan akışkanlardan birisi olan amonyak toksisitesi ve yanıcı özelliğinden dolayı yavaş yavaş yerini CFC ve HCFC'ler gibi sentetik soğutuculara bırakmıştır. Şekil 2'de genel olarak kullanılan soğutucu akışkanlar görülmektedir.

Soğutucu akışkan olarak kullanılan insan yapımı kimyasal maddelerin dünyaya olan zararlı etkileri yapılan bilimsel çalışmalar sonucunda ortaya çıkınca kullanımlarında bazı değişimler başlamıştır. İçerisinde klor ve brom da dahil olmak üzere ozon tabakasıda dahil olmak üzere çevre için zararlı maddeler ihitiva eden soğutucu akışkanların üretimi 1987 yılında imzalanan Uluslararası Montreal Protokolü ile kontrol altına alınmıştır. Böylece soğutucu maddelerin kullanımında yeni bir döneme girilmiş ve çevreye en az ve/veya hiç zarar vermeyen alternatif soğutucu akışkanların arayışı başlamıştır. 1 Ocak 1996 tarihinde CFC tipi soğutucu kimyasal akışkanların üretimi tamamen durdurulmuştur. 1989 yilına gelindiğinde ise ozon tabakasına zarar vermeyen hidroflorokarbon (HFC) kökenli R134a $\left(\mathrm{C}_{2} \mathrm{H}_{2} \mathrm{~F}_{4}\right)$ ve $\mathrm{R} 123\left(\mathrm{C}_{2} \mathrm{HF}_{3} \mathrm{Cl}_{2}\right)$ soğutucu akışkanlar bulunarak alternatif akışkanlar geliştirilmiştir. Alternatif soğutucu akışkanların seçiminde genel olarak dikkat edilmesi gereken kriterler [6,7]; temin edilebilirlik, termodinamik ve fiziksel özellikler, yanma özellikleri, ozon tüketme potansiyeli (ODP) değeri, küresel 1sınma potansiyeli (GWP) değeri, fiyat, zehirlilik özellikleri, malzeme uyumu, yă̆ değiş̧imi ve yağlarla uyumu olarak söylenebilir. 


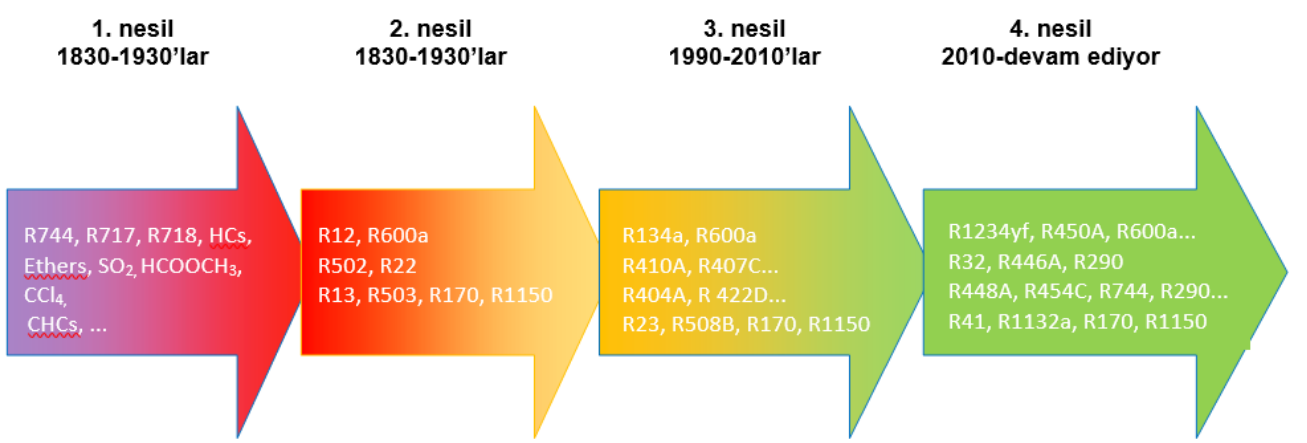

Şekil 1. Soğutucu akışkanların tarihsel gelişimi (Historical development of refrigerants)

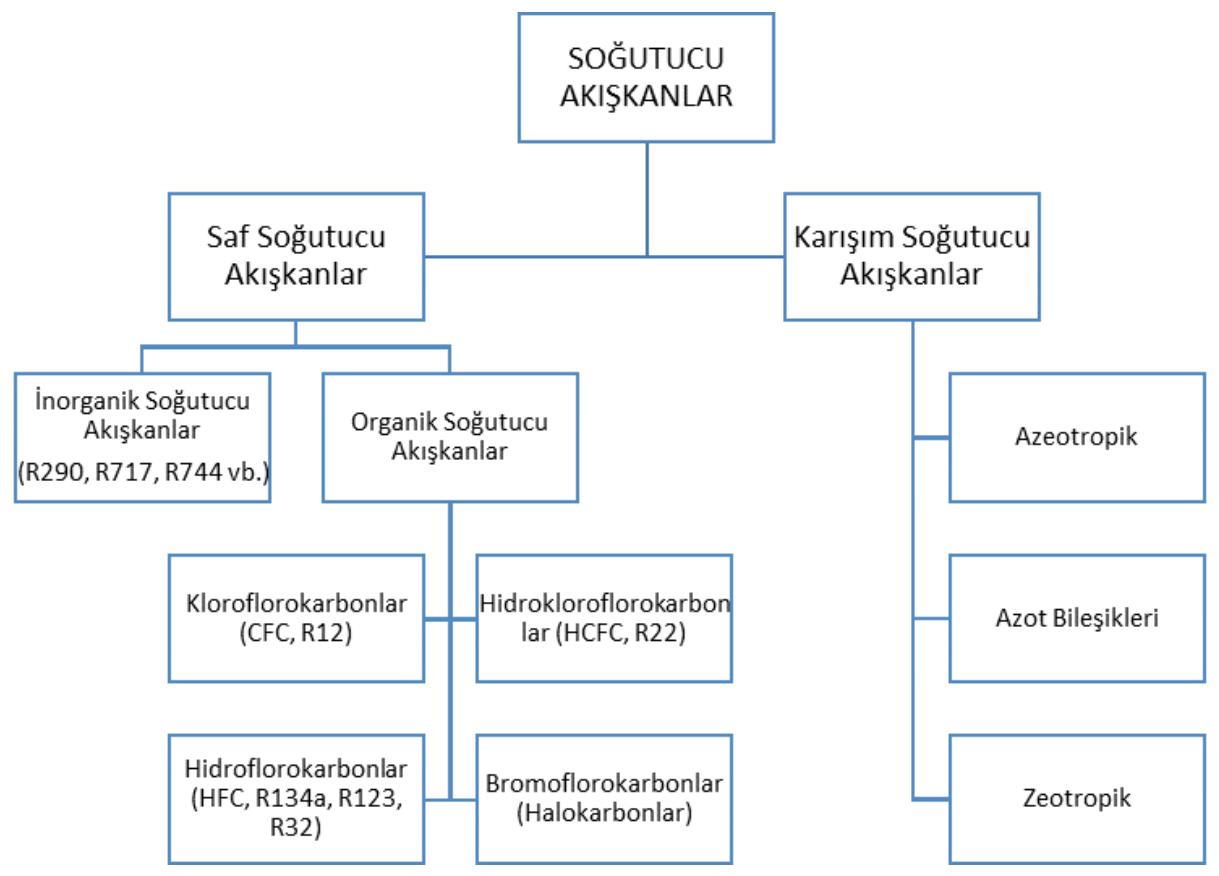

Şekil 2. Soğutucu akışkanlar(Refrigerants)

\section{SOĞUTU AKIŞKANLARIN ÇEVRESEL ETKILLERI (ENVIRONMENTAL EFFECTS OF REFRIGERANT)}

Yeryüzünden 12 ile $55 \mathrm{~km}$ yükseklikte bulunan ozon tabakası güneşten gelen zararlı ultraviyole ışınlarını soğurarak zararlı 1şınlara karşı dünyayı korumaktadır. Teknolojinin gelişmesiyle beraber yapılan araştırmalar ve keşifler sonucunda uzun süredir çeşitli amaçlar için yaygın olarak kullanılan soğutucu akışkanlardan HCFC, CFC ve halojen madde içeren akışkanların çevreye ve ozon tabakasına büyük zararlarının dokunduğu, ozon miktarında ciddi bir azalmaya neden olduğu gözlemlenmiştir [8]. Çeşitli prosesler için sistemlerde kullanılan içerisinde klor bulunan kimyasal bileşiklerden atmosfere kaçak olabilmektedir. Örneğin CFC'ler atmosferin troposfer katmanında oldukça kararlı olmalarına rağmen doğal yollarla stratosfer katmanına geçtiklerinde Eşitlik 1'de görüldüğü gibi ultraviyole 1şınları tarafindan parçalanmaya başlar. Böylece ozon tabakasının inceltilmesine neden olan klor atomları salınır. Ozon bileşiğinin yapısını bozup parçalanmasına ve oksijen oluşmasına neden olan bu serbest hale gelen klor atomlarıdır. Serbest haldeki klor atomu bir ozon bileşiği ile etkileştiğinde Eşitlik 2'deki gibi klormonoksit (CIO) ve oksijen molekülü $\left(\mathrm{O}_{2}\right)$ oluşmaktadır. Oluşan klormonoksit Eşitlik 3'de ifade edildiği gibi serbest halde bulunan bir oksijen atomu kimyasal tepkimeye girerek oksijen molekülü ve klor atomu oluşturur. Ozonun parçalanması aşağıda verilen kimyasal eşitlikler ile daha iyi açıklanabilmektedir.

$$
\begin{aligned}
& \mathrm{CFCI}_{3}+\mathrm{UV} \rightarrow \mathrm{CFCI}_{2}+\mathrm{CI} \\
& \mathrm{CI}+\mathrm{O}_{3} \rightarrow \mathrm{CIO}+\mathrm{O}_{2}
\end{aligned}
$$




$$
\mathrm{CIO}+\mathrm{O} \rightarrow \mathrm{O}_{2}+\mathrm{CI}
$$

Kimyasal kararlılığı yüksek olan CFC'ler atmosferde yapısı bozulmadan çok uzun süre kalabilmektedir. Serbest haldeki klorun atomunun başlattığ 1 bu kimyasal zincirin doğal yollarla atmosferin troposfer katmanına dönmeden önce 100,000 ozon molekülünü oksijene dönüştürebilmektedir [9].

Küresel ısınma ve iklim değişikliği sorunları ile ilgili uluslararası mücadeleyi sağlamak amacıyla 1997 yilında imzalanan Kyoto protokolü kapsamında listelenen florlu sera gazları ile bünyesinde florlu sera gazı ihtiva eden ürün ve ekipmanların kullanım usul ve esaslarını düzenlemek ve florlu sera gazı kaynaklı emisyonları kontrol altında tutmak maksadiyla yapılan Florlu Gazlar Yönetmeliği Avrupa Birliği tarafindan 2006 yılında yayınlanmış 2014 yılında ise revizyonu yapılarak 1 Ocak 2015 tarihinde yürürlüğe girmiştir. Çeşitli uygulamalar ve sektörlerde kullanılan insan yapımı kimyasallar olan florlu gazlar; sülfürhegzaflor $\left(\mathrm{SF}_{6}\right)$, perflorokarbonlar $(\mathrm{PFC})$ ve hidroflorokarbonlar (HFC) olup, bu kimyasallar çeşitli sanayi tesislerinde ve/veya konutların iklimlendirilmesinde, 1sitılmasında, soğutulmasında, yangın söndürücü gibi geniş uygulama alanlarında kullanılmaktadırlar. Bununla birlikte, sıfir ODP değerine sahip olmasına rağmen F- gazların iklim değişikliğine zararlı etkileri de mevcuttur.

2015'te yürürlüğe giren "F Gaz Yönetmeliğì" ile kullanımı sınırlandırılan soğutucu akışkanları içeren sistemler yerine soğutucu akışkan olarak çevreye duyarlı doğal soğutucu akışkanların tercih edildiği sistemlerin geliştirilmesinin öneminin daha da arttığ görülmektedir. Enerjinin etkin kullanımı ve enerji yoğunluğunun azaltılması için atılan adımlar çerçevesinde konut ve endüstriyel kullanım fark etmeksizin ortak bir hedeftir.

Soğutucu akışkanların, ozon tabakasının incelmesi ve küresel ısınmanın etkisini arttırması gibi çevreye olan zararlı etkilerinden dolayı birçok uluslararası yönetmeliğin yayımlanmasına yol açmıştır. Böylece de süreç içerisinde alternatif soğutucu akışkanlar kavramı ortaya çıkmıştır. Bu süreç içerisinde sürekli bir değişim yaşanmış ve soğutucu akışkan üreticisi olan firmalar ihracat yaptıkları ülkelerin çevre yönetmeliklerine uygun soğutucu akışkanlar geliştirmek zorunda kalmıştır.
3. DOĞAL SOĞUTUCU AKIŞKANLARIN ÖZELLIKKLERİ VE DOĞAL SOĞUTUCU AKIŞKANLARDA SON GELIŞMELER (CHARACTERISTICS OF NATURAL COOLING FLUIDS AND LATEST DEVELOPMENTS IN NATURAL COOLING FLUIDS)

Isıtma ve soğutma endüstrisinde kullanılan akışkanlardan ekonomik, güvenli, kolay temin edilmesi gibi istenilen özelliklerin yanı sıra soğutucu akışkanın yaşadığımız dünyaya çevresel olarak zarar vermemesi gerekmektedir. $\mathrm{Bu}$ sebeple zaman içerisinde 1sitma ve soğutma endüstrisinde pek çok farklı özellikte soğutucu akışkan üretimi gerçekleştirilmiş ve kullanılmıştır. Geçmişte bir dönem kullanılan amonyak (R717), karbondioksit (R744), su (R718) gibi soğutucu akışkanların yerini bir müddet sonra laboratuvar ortamlarında geliştirilen HCFC ve CFC gibi soğutucu akışkanlar almış ve yoğun bir şekilde kullanılmıştır. İnsan yapımı yaygın olarak kullanılan soğutucu akışkanların farklı karakteristik davranışları ile avantaj ve dezavantajlarının olması kullanım yerlerinin çeşitliliğini arttırmıştır. Bununla beraber zaman içerisinde ozon tabakasına zararlı olduğu anlaşılan CFC gibi çeşitli akışkanların kullanımı uluslararası antlaşmalarda yasaklanmış ve/veya kısıtlanmıştır. Sonraki süreçlerde $\mathrm{CFC}$ gruba alternatif olarak kullanılan daha az ozon tahribatına sahip olan HCFC grup akışkanlar kullanılmıştır. HCFC grup soğutucu akışkanlara da alternatif olarak hidrojen, flor ve karbon içeren ozon tahribatları düşük olan fakat GWP sahip olan HFC grubu soğutucu akışkanlar kullanılmaya başlanmıştır. R32, R134a, R410A, R407C bu gruptaki bazı soğutucu akışkanlara örnek olarak verilebilir. HFC grup soğutucu akışkanlardan sık kullanılan R32 soğutkanı HFC grup akışkanlar arasından en dengeli çözüm sunan akışkandır. Aynı grupta yer almasına rağmen R410A akışkanı ile R32 akışkanı test edilmiştir. Değişken hızlı bir kompresörün $16 \mathrm{~kW}$ gücünde performans analizi sonucu R32 soğutucu akışkanının soğutma performansının R410A'dan daha yüksek olduğu ifade edilmiştir [10].

Zeotrop karışımlarda genelde kritik nokta sıcaklığı ile hacimsel soğutma kapasitesi arasında uyum olduğu ve saf akışkanların COP değerlerinin çoğunlukla karışımların COP değerlerini etkilediği ifade edilmiştir [11].

Ozon tüketimi yapmayan, doğal, enerji verimliliğgi yüksek, zehirleyici etkileri olmayan, GWP değeri göz ard1 edilebilir seviyede olan hidrokarbonlar doğal 
soğutucu akışkan olarak adlandırılırlar. En yaygın bilinen hidrokarbonlar bütan (R600), isobütan (R600a), propan (R290), propilen (1270), etan (R170) ve etilen (R1150)'dir. Hidrokarbonlar yüksek yoğuşma sıcaklıklarında bile yüksek COP sağlarlar. Ayrıca yüksek 1S1 transfer özelliğine sahiptirler. Yanıc1, parlayıcı, kokusuz olması ve şarj miktarı kısıtı en önemli dezavantajlarıdır [9].

Montreal Protokolü gereği ozon tahribatı az olan veya hiç olmayan alternatif akışkanların arayışına gidilmiştir. Doğanın kimyasal ve biyolojik doğal döngülerinde meydana gelen doğal soğutucu akışkanlar CFC, HCFC ve HFC gibi soğutucu akışkanların çevreye verdiği zararlara karşı alternatif teşkil etmektedir. Sıfır ODP ve düşük GWP değerleriyle sahip oldukları çevresel özelikleri sayesinde doğal soğutucu akışkanlar günümüzde ve gelecekte kullanılabilirliği büyük önem arz etmektedir. Bazı doğal ve kimyasal soğutucu akışkanların özellikleri Tablo 1'de gösterilmiştir [12].

Tablo 1. Bazı soğutucu akışkanların özellikleri(Properties of some refrigerants)

\begin{tabular}{|c|c|c|c|c|c|c|c|c|}
\hline $\begin{array}{l}\text { Soğutucu } \\
\text { Akışkan }\end{array}$ & $\begin{array}{c}\text { ASHARE } \\
\text { Sinıflandırm } \\
\text { ası }\end{array}$ & $\begin{array}{c}\text { Moleküler } \\
\text { Formül }\end{array}$ & $\begin{array}{c}\text { Emniyet } \\
\text { Sinıfi }\end{array}$ & $\begin{array}{c}\text { Küresel } \\
\text { Isınma } \\
\text { Potansiyeli } \\
\text { (GWP) }\end{array}$ & $\begin{array}{c}\text { Ozon } \\
\text { Tüketme } \\
\text { Potansiyeli } \\
\text { (ODP) }\end{array}$ & $\begin{array}{c}\text { Kritik } \\
\text { Sicaklık } \\
\left({ }^{\circ} \mathrm{C}\right)\end{array}$ & $\begin{array}{l}\text { Kritik } \\
\text { Basınç } \\
(\mathrm{MPa})\end{array}$ & $\begin{array}{c}\text { Normal } \\
\text { Kaynama } \\
\text { Sicaklığı } \\
\left({ }^{\circ} \mathrm{C}\right)\end{array}$ \\
\hline
\end{tabular}

Doğal Soğutucu Akışkanlar

$\begin{array}{lllllllll}\text { Karbondioksit } & \mathrm{R} 744 & \mathrm{CO}_{2} & \mathrm{~A} 1 & 1 & 0 & 30,98 & 7,38 & -78,46 \\ \text { Propan } & \mathrm{R} 290 & \mathrm{C}_{3} \mathrm{H}_{8} & \mathrm{~A} 3 & 3 & 0 & 96,74 & 4,25 & -42,11 \\ \text { Izobütan } & \mathrm{R} 600 \mathrm{a} & \mathrm{C}_{4} \mathrm{H}_{10} & \mathrm{~A} 3 & 4 & 0 & 134,66 & 3,83 \\ \text { Propilen } & \mathrm{R} 1270 & \mathrm{C}_{3} \mathrm{H}_{6} & \mathrm{~A} 3 & 1,8 & 0 & 91,06 & 4,55 \\ \text { Amonyak } & \mathrm{R} 717 & \mathrm{NH}_{3} & \mathrm{~B} 2 \mathrm{~L} & 0 & 0 & 11,75 \\ & & & & & & 0 & 132,25 & 11,33\end{array}$

Kimyasal Soğutucu Akışkanlar

\begin{tabular}{llllcllll}
$\begin{array}{l}\text { Tetrafloroetan } \\
\text { Klorodifloro }\end{array}$ & $\mathrm{R} 134 \mathrm{a}$ & $\mathrm{CH}_{2} \mathrm{FCF}_{3}$ & $\mathrm{~A} 1$ & 1300 & 0 & 101,06 & 4,06 & $-26,07$ \\
$\begin{array}{l}\text { metan } \\
\begin{array}{l}\text { Diklorodifloro } \\
\text { metan }\end{array}\end{array}$ & $\mathrm{R} 22$ & $\mathrm{CHClF}_{2}$ & $\mathrm{~A} 1$ & 1760 & 0,03 & 96,15 & 4,99 & $-40,81$ \\
\hline
\end{tabular}

Sistemde kullanılacak bir soğutucu akışkandan buharlaşma gizli 1sısının yüksek olması, zehirleyici ve yanıcı olmaması, temasta bulunduğu yüzeylere ve malzemeye zarar vermemesi, uyumlu olması istenir. Fakat her soğutucu akışkan bu özellikleri karşılayamaz. Gerekli önlemler alınarak akışkana göre tasarlanmış sistemler sayesinde bahsi geçen dezavantajlara karşı tatmin edici çözümler ile çeşitli soğutucu akışkanlar uygulamalarda kullanılabilir. Bu soğutucu akışkanlara örnek olarak R717 soğutucu akışkan verilebilir. Hem ekonomik hem de kolay ulaşılabilir olmasının yanı sıra sahip olduğu sıfır ODP değeri ve GWP değeri ile R717 geçmişte, günümüzde ve hatta gelecekte çevreye zararlı olan CFC, HCFC gibi soğutucu akışkanlara karşı güçlü bir alternatiftir. Fakat zehirleyici, yanıcı ve patlayıcı olma özellikleri vardır. R717, zehirleyici ve yanıcı özelliğinden dolayı özel güvenlik önlemleri gerektirse de CFC, HCFC ve HFC'lere kıyasla termodinamik özellikleri çok daha iyidir. Zehirleyici olma özelliğine rağmen sahip olduğu ayırt edici koku 5 ppm kadar küçük konsantrasyonlarda meydana gelebilecek sızıntılar insanlar tarafından fark edilebilmektedir [13]. Küçük soğutma yükleri az miktarda soğutucu akışkan gerektiğinden kontrolü zorlaşmaktadır. $\mathrm{Bu}$ yüzden ihtiyaç duyulan küçük yükleri karşılamakta pek kullanışlı değildir. Atmosfer basıncında buharlaşma sıcaklığı $-33,3^{\circ} \mathrm{C}$ civarındadır. Kritik sıcaklık değeri $132,35{ }^{\circ} \mathrm{C}$ ve kritik basınç değeri 113,53 bar'dır. Sahip olduğu özellikler sayesinde R717 1sitıldığında sudan kolayca ayrılabildiği için absorpsiyonlu soğutma sistemlerinde rahatlıkla kullanılabilmektedir. Ozon tahribatına ve küresel ısınmaya karşı güçlü bir alternatif olan R717 sahip olduğu avantajlar ile endüstride bazı kullanım alanlarına sahiptir. Sentetik soğutucu akışkanlara kıyasla azot döngüsünün bir yan ürünü olan R717 daha ucuzdur. Fakat R717 diğer ortam koşulları da sağlandığında bakır ve bakır alaşımlarına zarar verebilir. Bu durum $\mathrm{CFC}$ ve/veya HCFC'lerle çalışan günümüzde çoğunlukla kullanılan bakır boru sistemlerine karşı dezavantaj oluşturmaktadır [14]. Bundan dolayı çelik borulama 
sistemleri gibi tesisatlarda kullanılma zorunluluğu vardır.

R717 soğutucu akışkanı buhar sıkıştırmalı çevrimlerde kullanıldığında çok iyi verime sahiptir. Ayrıca R717 ve kompresör yağının karışabilirliği zayıftır. $\mathrm{Bu}$ özelliği ile yangın riski azaltılmakla beraber daha kolay ayrılmasını da sağlar. Sistemin dezavantajı yağı kompresöre geri döndürmek için ayrı bir mekanizmaya ihtiyaç duymasıdır [9]. Dikmen ve arkadaşları düşük GWP değerine sahip soğutucu akışkanlar ile yaptıkları çalışmada çeşitli soğutucu akışkan çiftleri ile çalışan kaskad soğutma sistemlerinin performanslarını karşılaştırmışlardır. Sistem çalışma performansının alçak basınç çevriminde yoğuşma sıcaklığından ve yüksek basınç çevriminde buharlaşma sıcaklığından etkilendiğini gözlemlemişlerdir. Sonuçta en yüksek performans katsayısı (COP) değerini R454C/R717 soğutucu akışkan çiftiyle çalışan sistemde 3,16 olarak ve bunun yanında en küçük COP değeri ise R744/R290 soğutucu akışkan çiftiyle çalışan sistemde 2,42 olarak bulunmuştur [15]. Kaskad sistemlerde birincil çevrimin soğutucu akışkanı olarak kullanılabilen R717 ikincil soğutucu akışkan olarak suyla beraber de kullanılabilmektedir. R717 bölgesel 1sitma ve/veya soğutma uygulamalarında, endüstriyel 1S1 pompalarında, gıda ürünlerinin soğuk ortamlarda muhafazasında, bazı içecek ve süt ürünlerinin soğutulmasında ve depolanmasında, buz üretiminde ve donmuş paketleme uygulamalarında kullanilabilmektedir.

Boumaza (2010) tarafindan R22 soğutucu akışkana alternatif 3 farklı soğutucu akışkanın (R290, R717, R600) 3 farklı kondenzasyon sicaklıklarında $\left(30^{\circ} \mathrm{C}, 40^{\circ} \mathrm{C}, 50^{\circ} \mathrm{C}\right)$ çalışan akışkanın termodinamik analizinin simülasyonu yapılmıştır. Yapılan çalışma ile evaporatör ve kondenser sicaklıklarının COP, hacimsel soğutma kapasitesi (VRC), kompresör deşarj sıcaklığı ve kompresör yük kapasitesi üzerine etkisi incelenmiştir. COP için R290'ın R22 ile benzer sonuçları gösterirken R717 ve R600 soğutucu akışkanları R22 den düşük COP'ye sahip özellik sergilemiştir. R22 ile kıyaslandığında en yüksek hacimsel soğutma kapasitesi değerini R717 göstermiştir. Elde edilen sonuçlar R290, R22 ye benzer termodinamik performansa sahip olsa da R290'ın düşük akış hızına sahip olması ekipmanların da küçük olmasını gerektirmektedir. Bu nedenle R290 daha küçük soğutma yükleri için R22soğutucu akışkanın yerine kullanılabileceğini göstermiştir. R717 sahip olduğu yüksek gizli ısıya rağmen yanıcı, zehirleyici etkilerinden dolayı uygulamada fazladan güvenlik teçhizatları gerektirmektedir. İncelenen doğal soğutucu akışkanlar soğutma, klima ve 1s1 pompalarında kullanılmak için potansiyel aday olarak görülmektedir [16].

R744 yaygın olarak kullanılan soğutucu akışkanlardan bir tanesidir. Gazoz, kola vb. içecekler için tasarlanan soğutma sistemlerinde kullanılabilen R744, amonyak haricindeki diğer soğutucu akışkanlara kıyasla daha yüksek gizli 1s1, özgül 1s1, yoğunluk, termal iletkenlik ve daha düşük viskozite göstermesi ile de diğer soğutucu akışkanlara karş1 üstünlük sahibidir. Ayrıca sıfır ODP çok düşük GWP'ye sahip olması zehirleyici ve yanıcı olmaması R744'ü halokarbon soğutuculara karşı önemli bir alternatif kılmaktadır. Soğutma sanayisinin başladığ ilk zamanlarda yaygın bir şekilde kullanılan R744 soğutucu akışkanının kritik noktasının sıcaklığı düşük $\left(31,06{ }^{\circ} \mathrm{C}\right)$ ve basıncinın yüksek olması $(73,8$ bar) uygulamalarda kullanılmasını sinırlamaktaydı. Buhar sıkıştırmalı ısıtma ve/veya soğutma çevrimlerinde bu sorunu çözmek amaçlı geliştirilen transkritik çevrimler ile uygulamaların sayısı artmıştır. Transkritik çevrimlerde R744 soğutucu akışkanı kritik noktasının üstüne çıkabilmektedir. $\mathrm{Bu}$ sistemlerde kondenser yerine gaz soğutucu adı verilen ekipman kullanılır. Kim vd. iklimlendirme ve 1sı pompası uygulamalarında kullanılan R744 soğutucu akışkanın transkritik çevrim teknolojisi için yapılan son gelişmeleri araştırmışlardır. Araştırmalarında R744'ün hacimsel 1 sı transfer kapasitesinin $0{ }^{\circ} \mathrm{C}$ 'de $22,545 \mathrm{~kJ} / \mathrm{m}^{3}$ olduğunu ve $\mathrm{HC}, \mathrm{HFC}, \mathrm{HCFC}$ ve $\mathrm{CFC}$ soğutkanlarına kiyasla hacimsel isı transfer kapasitelerinin 3 ile 10 kat daha yüksek olduğunu ifade etmişlerdir [17]. R744 soğutucu akışkanın yüksek hacimsel 1sı transfer kapasitesine sahip olması 1sıtma ya da soğutma amaçlı tasarlanan sistemin boyutlarının küçük olması anlamına da gelmektedir. R744 soğutucu akışkanı diğer alternatif soğutucu akışkanlarla karşılaştırıldığında $\left(-5 /-30^{\circ} \mathrm{C}\right)$ uygulama şartlarında R717'ye kıyasla kompresör süpürme hacmi 1/9 oranında daha küçüktür [18]. R134a'ya göre gizli buharlaşma 1sısı daha fazla olduğu için soğutmada gerekli olan soğutucu akışkan miktarı daha az olmaktadır. Daha az soğutucu akışkan miktarı beraberinde akışkanın sistem içerisinde hızının da düşük olmasına ve böylece sürtünme kaynaklı enerji kayıplarının daha az olacağı anlamına gelmektedir [19]. $\mathrm{Bu}$ avantajlarına rağmen $\mathrm{R} 744$ soğutucu akışkanın kritik noktası basınç değerinin diğer soğutucu akışkanlara kıyasla yüksek olması sistem güvenliği açısından tasarımında kullanılacak ekipmanları etkilemektedir. $\mathrm{Bu}$ yüzden ekipman 
üreticileri, yüksek basınçlarda uygun mukavemeti gösterebilecek ürünler geliştirmelidir.

Dünya üzerinde hemen hemen her yerde ve bolca bulunan su iklimlendirme sistemlerinde kullanılmaktadır. $0{ }^{\circ} \mathrm{C}$ 'de sıvı fazdan katı faza geçtiğ için kullanım alanı sınırlıdır. Bununla beraber yüksek gizli isıya sahiptir. R718'in kritik noktasının sıcaklık ve basınç değerleri sırasıyla $374,14{ }^{\circ} \mathrm{C}$ ve 220,89 bar değerindedir.

Diğer soğutucu akışkanlarla karşılaştırıldığında suyun sahip olduğu avantajların bir kısmı aşağıda verilmiştir [20]:

- Küresel ısınma potansiyeli sifirdır $(\mathrm{GWP}=0)$.

- Ozon tüketme potansiyeli sifirdır (ODP =0).

- Yanıci olmadığı gibi zehirleyici etkisi de yoktur.

- Çevreye zararlı olmayıp kullanımı kolaydır.

- R718'in kullanımı için gelecekte herhangi bir kisitlama yoktur.

- Kullanım sonrası imha işlemlerinde sorun oluşturmaz.

- Sistem buharlaşma ve yoğuşma için doğrudan 1S1 eşanjörleri kullanabilir. Bu sayede R718 kullanan sistemlerin COP değerleri çok yüksek olabilmektedir. - Sitemin buharlaşma sicaklığına bağlı olarak CFC'lerle rekabet edebilecek COP değerine sahiptir.

- Sistemde kullanılacak akışkanın eldesi için musluklar, arıtılmış atık sular veya filtre edilen nehir suları kullanılabilir.

Diğer bir yandan, Hidrofloroolefin (HFO) soğutucular, karbon, hidrojen ve flordan oluşan doymamış organik bileşiklerdir. HFO soğutucular, kloroflorokarbonlar (CFC'ler), hidrokloroflorokarbon (HCFC'ler) ve hidroflorokarbonlar (HFC'ler) gibi geleneksel doymuş halohidrokarbon soğutuculardan farklı olan en az bir çift bağ $(\mathrm{C}=\mathrm{C})$ içerir. Diğer bir önemli fark, HFO'ların normalde klorsuz olma ve kısa atmosferik ömürlere sahip olma moleküler özellikleri nedeniyle sıfır ODP ve son derece düşük GWP sergilemesidir. $\mathrm{Bu}$ nedenle, HFO'lar son on y1lda giderek artan bir ilgi görmekte ve bunlardan bazıları gerçek koşullar altında yeni nesil soğutucu akışkanlar için aday olarak görülmektedir. Çünkü mevcut yaygın olarak kullanılan çevre dostu olmayan doymuş halohidrokarbon soğutkanların çoğunun, Montreal Protokolü, Kyoto Protokolü, Paris Anlaşması, F-Gaz Yönetmelikleri dahil olmak üzere uluslararası iklim sözleşmelerinin gerekliliklerine göre aşamalı olarak kaldırılması planlanmıştır. HFO'lar, HFC'lerin GWP'sinin \% 0,1'i ile "dördüncü nesil" soğutucu akışkanlar olarak geliştirilmektedir ve bu akışkanlar; HFO-1234yf, HFO-1234ze, HFO-1336mzz-Z, HFO1336mzz-E'dir. HFO sınıfındaki birçok soğutucu akışkan, doğal olarak kararlı kimyasal ve inerttir, toksik değildir ve yanmaz veya hafif yanıcıdır. Birçok HFO, ortak sıcaklıklarda soğutma için yararlı olacak uygun donma ve kaynama noktalarına sahiptir. Ayrıca kojenerasyon, 1S1 geri kazanımı ve orta sicaklıkta 1S1 pompaları gibi yüksek sicaklık uygulamalarının yanı sıra şişirici maddeler olarak, yani yalıtım köpüklerinin üretiminde, gida endüstrisinde, inşaat malzemelerinde de umut vaat etmektedirler [21].

\section{4. ÇALIŞMALARIN İNCELENMESİ (REVIEW OF STUDIES)}

Dikmen ve arkadaşları (2020), kaskad soğutma sisteminde düşük GWP değerine sahip soğutkanları kullanarak sistemin karşılaştırmalı performans analizini yapmışlardır. Yapılan çalışmada en yüksek COP değerini 3,16 ile R454C/R717 soğutucu akışkan çiftiyle çalışan sistemde bulmuşlardır [15].

Boumaza (2010), R22'ye alternatif 3 farklı soğutucu akışkanın (R290, R717, R600) 3 farklı kondenzasyon sicaklıklarında $\left(30^{\circ} \mathrm{C}, 40^{\circ} \mathrm{C}, 50^{\circ} \mathrm{C}\right)$ çalışan akışkanın termodinamik analizinin simülasyonu yapılmıştır. R290 soğutucu akışkanı R22 ile benzer COP değerleri gösterirken R717 ve R600 soğutucu akışkanları R22'den düşük COP değeri göstermiştir. R290 soğutucu akışkanının küçük soğutma yüklerinin karşılanmasında R22'ye alternatif olabileceğini belirtmişler ve buna ek olarak R717 akışkanının yanıcı ve zehirleyici özelliğinden ek güvenlik önlemlerinin alınması gerektiğini vurgulamışlardır [16].

Kızılkan (2015), ozon tahribatına ve küresel ısınmaya yol açan akışkanlara alternatif olabilecek bazı doğal ve klasik akışkanları bir soğuk hava deposu için karşılaştırmış ve termodinamiğin birinci ve ikinci yasasına göre incelemiştir. Çalışmasında en yüksek COP değerini R600 soğutucu akışkan ile 2,5 olarak bulunmuştur. R717 ve R290 soğutucu akışkanların COP değerleri ise sirasiyla 2,462 ve 2,369 olarak hesaplanmıştır. En düşük COP değerleri R744 için 1,482 ve R170 için 1,463 olarak elde edilmiştir [22].

Choudhari ve Sapali (2017), soğutma sistemlerinde kullanılan soğutucu akışkan R22 ile ODP değeri 0 ve düşük GWP değerine sahip R290 soğutucu akışkanının buhar sıkıştırmalı çevrimde termodinamik performansını karşılaştırmışlardır. R290 kullanıldığında sistemin COP değerinin R22'ye kıyasla çok az düşük olduğunu ve R290'a yönelik tasarlanacak özel sistemler sayesinde uygulamada R22 ye iyi bir potansiyel alternatif akışkan olabileceğini ifade etmişlerdir [23]. 
Pitarch, ve arkadaşları (2017), doğal soğutucu akışkanlar kullanarak sıcak su üretmek için farklı 1sı pompası tasarımları arasında bir karşılaştırma yapmışlardır. Propan, subkritik çevrimli sistemler mevcut $\mathrm{CO}_{2}$ sistemleri ile karşılaștırıldı̆̆ında su sıcaklığı artışına bağlı olarak \% 5 ile \% 20 arasında daha yüksek bir COP göstermiştir. Propan subkritik çevrimle çalışan sistem $\mathrm{CO}_{2}$ sistemlere göre $\mathrm{COP}$ değerinde \%11'e kadar bir iyileşme ile suyu $30^{\circ} \mathrm{C}$ 'den $90{ }^{\circ} \mathrm{C}^{\prime}$ ye kadar ısıtabileceğini ifade etmişlerdir [24].

Erten ve Uludağ (2019), 3,54 kW soğutma kapasiteli R404A ve R290 soğutucu akışkanı ile çalışan buhar sıkıştırmalı iki ayrı soğutma sistemini test etmişlerdir. Testler aynı şartlar altında (Class-3 25 ${ }^{\circ} \mathrm{C}$ sıcaklık \%60 bağıl nem) gerçekleştirilmiştir. R290 soğutucu akışkanlı soğutma sisteminin performans katsayısı değeri 2,5 olarak hesaplanmıştır. R404Asoğutucu akışkanlı soğutma sisteminin COP'sini 2,2 olarak hesaplanmıştır. Yani bu sistem R290'lı (Propanl1) sistem ile daha enerji verimli hale getirilmiştir [25].

Shaik ve Babu (2017), propilen (R1270) ve propan (R290) içeren ikili soğutucu akışkan karışımlarını, pencere tipi bir klima cihazında teorik COP değerini araştırarak R22 akışkanı ile karşılaştırma yapmışlardır. Çalışmanın sonunda kütlesel olarak \%75 R1270 ve \%25 R290 karıșımının R22'ye en yakın COP değerini sağladığını tespit ederek, konut klima uygulamalarında kullanılan R22 akışkanı yerine uygun bir alternatif soğutucu akışkan olduğunu tespit etmişlerdir [26].

Özyurt ve arkadaşları (2015), kaskad bir soğutma çevriminin teorik analizini yapmışlardır. Karbondioksit döngüsünde yoğuşturucu sıcaklığının yükseltilmesiyle ekserji yıkımlarında azalma olduğunu ve buna bağlı olarak COP değeri ile ikinci yasa verimimin arttığını gözlemlemişlerdir. R717 yoğuşturucusunu sistemdeki ekserji kayıplarının nedeni olarak belirlemiş̧ler ve 1sı değiştiricideki sıcaklık farkındaki artışın sistemin COP'sini ve ikinci yasa verimini düşürdüğünü tespit etmişlerdir [27].

Cho (2015), güneş enerjisi destekli 1s1 pompası sistemlerinin ekserji ve COP analizlerini farklı hava koşullarında yapmıştır. Bulutlu hava koşullarında R22 soğutucu akışkanlı sistemin COP değeri 3,21, R744 soğutucu akışkanlı sistemin COP değeri 2,75; güneşli hava koşullarında ise COP değerleri \%20,2 artarken, güneş kollektörünün veriminin yaklaşık \%14,2 azaldığını gözlemlemiştir. İkinci yasa verimleri kıyaslandığında da R22 soğutucu akışkanlı sistemin veriminin R744 soğutucu akışkanlı sistemin veriminden $\% 6,2$ daha yüksek olduğunu belirtmişlerdir [28].

Nguyen ve arkadaşları (2019), R744 soğutucu akışkanlı 1sı pompası çevriminde 1sıtma modunda 1S1 değiştiricinin sistem performansı üzerindeki etkisini anlık enerji simülasyonları ile değerlendirmişlerdir. Aynı çalışma şartlarında ara 1sı değiştiricili sistemin ara 1Sı değiştirici kullanılmayan sistemden \%22 daha yüksek COP değerine sahip olduğunu gözlemlemişlerdir [29].

Silva ve arkadaşları (2012), süpermarket uygulamalarında $\mathrm{CO}_{2}-\mathrm{R} 404 \mathrm{~A}$ soğutucu akışkanlı kaskad soğutma sistemini $\left(\mathrm{CO}_{2}\right.$ subkritik olarak), R404A soğutucu akışkanlı sistemi ve R22 soğutucu akışkanlı sistemi enerji verimliliği yönünden değerlendirmişlerdir. Değerlendirme sonucunda $\mathrm{CO}_{2}$ kullanılan kaskad soğutma çevrimi diğer iki sistem ile karşılaştırıldığında elektrik enerjisi tüketiminin \%24$\% 13$ arasında azaldığı ve düşük sıkıştırma oranı ile $\mathrm{CO}_{2}$ kompresörünün ömrünün uzadığını gözlemlemişlerdir [30].

Yolcan (2017), güneş enerjisi destekli toprak kaynaklı 1sı pompası sisteminde buharlaşma sıcaklı̆̆ yükseldikçe ve yoğuşma sıcaklığı düştükçe, COP değerinin yükseldiğini gözlemlemiştir. Elde etmiş olduğu sonuçlara göre en COP değerini R134a ve R600a, en düşük COP değerini ise R410A ve R507A soğutucu akışkanlarının sağladığını belirtmiştir. Kompresörlerin ekserji verimini \%78 - \%92, kondenserlerin ekserji verimini \%94 - \%98, genleşme valflerinin ekserji verimini $\% 69-\% 95$ aralığında ve evaporatörlerin verimini $\% 28-\% 86$ aralığında bulmuştur [31].

Coulbourne ve Ritter (2000), \%45,2/54,8 oranında R290/R600a karışımının hidrokarbon karışımları arasında beğenildiğini vurgulayarak, kimyasal kararlılıkta olup hermetik tip kompresörlerde metal olmayan ekipmanlarla tepkime yapmayan özellikte olduğunu göstermişlerdir [32].

Boran ve arkadaşları (2015), farklı miktarlarda kütle içeren R134a/R152a karışımlarının performanslarını deneysel olarak bir 1S1 pompası sisteminde incelemişlerdir. İncelemelerinde R152a soğutucu akışkanının oranının artması ısıtma COP'sinin \%5-23 arasında, soğutma COP'sinin ise \%6-28 arasında arttığını tespit etmişlerdir [33]. 
Lee ve $\mathrm{Su}$ (2002), soğutma çevrimine $150 \mathrm{~g}$ R600a şarj etmişlerdir. Soğuk depo uygulaması için $4{ }^{\circ} \mathrm{C}$ ve dondurma uygulamaları için $\quad-10 \quad{ }^{\circ} \mathrm{C}$ soğutma sıcaklıklarında deneysel olarak karşılaştırmışlardır. Sonuç olarak, COP değeri soğuk depo uygulamasında 4,5 olarak dondurma uygulamasinda ise 3,5 olarak tespit etmişlerdir [34].

Ender (2018), R404A soğutucu akışkanlı buhar sıkıştırmalı soğutma çevriminde sadece R404A soğutucu akışkanın yerine R442A ve R453A kullanılmasını deneysel olarak ele almıştır. Yapılan deneyler sonucu R442A ve R453A soğutucu akışkanlarının soğutma kapasitelerinin sırayla R404A'dan \%6,92 ve \%3,10 daha yüksek olduğunu gözlemlemiştir. Ayrıca iç 1sı değiştirici kullanılırsa sistemde soğutma kapasitelerinin $\% 19,63$ ve $\% 24,0$ artış gösterdiğini de gözlemlemiştir [35].

Hocaoğlu (2018), 1s1 pompası sistemi ile çalışmakta olan nem alma cihazında sistem parametrelerinin yoğuşma performansı ve yoğuşma verimi üzerine etkisini teorik hesaplamalar ve deneysel çalışmalar ile incelemiş ve karşılaştırmıştır. Deneysel çalışmalarda $150 \mathrm{~g}$ yerine $110 \mathrm{~g}$ R290 soğutucu akışkan şarjı kullanılması, buharlaştırıcı kapasitesi ve aşırı 1sıtma sıcaklığını çok fazla etkilemiştir. $110 \mathrm{~g}$ testlerinde soğutucu akışkanın kullanılan buharlaştırıcıyı doyuramadığı, aşııı kızdırma sıcaklığının istenilen sicaklık aralığının dışında kaldığını ve faz değişimi için gerekli gizli ısıdan etkin şekilde yararlanamadığını deneysel veriler ile tespit etmiştir. Bunların sonucunda $110 \mathrm{~g}$ çalışmalarında 150 g'a göre yoğuşma performansı ve yoğuşma veriminde \%15'lik bir azalma gözlemlemiştir [36].

Başaran (2019), 1S1 pompalı çamaşır kurutma makinesi deney düzeneğinde farklı soğutucu akışkanların, sistem iç hacminin, kompresör strok hacminin ve kılcal boru uzunluğunun sistemin COP'sine ve kurutma sonu nem oranına etkilerini incelemiştir. R290 soğutucu akışkan $8,2 \mathrm{~cm}^{3}$ kompresör strok hacmi, $7 \mathrm{~mm}$ boru çapl buharlaştırıcı, $5 \mathrm{~mm}$ boru çaplı yoğuşturucu ve farklı kılcal boru uzunlukları ile yapılan testlerde optimum COP değeri $1500 \mathrm{~mm}$ kılcal boru uzunluğundadır. R290 soğutucu akışkan, $7 \mathrm{~mm}$ boru çaplı buharlaştırıcı, $5 \mathrm{~mm}$ boru çaplı yoğuşturucu, $1200 \mathrm{~mm}$ kılcal boru uzunluğu ve farklı kompresör strok hacmi ile yapılan testlerde, $6,25 \mathrm{~cm}^{3}$ kompresör strok hacmi kurutma sonu enerjinin \%9 iyileştiği ancak kurutma sonu nem oranının limit dışında olduğunu ve $6,75 \mathrm{~cm}^{3}$ kompresör hacmi ile yapılan testlerde kurutma sonu enerji \%4 seviyesinde azalma göstermiştir [37].
Vural (2019), çalışmasında hidrokloroflorokarbon soğutucu akışkanı ile çalışan klima cihazının ozon dostu HFC-417A ve HFC-422D soğutucu akışkanlarıyla yapılan ölçümleri ile, soğutma kapasitesi ve COP gibi enerji parametrelerini deneysel olarak araştırmıştır. R22 soğutucu akışkanlı sistemin soğutma kapasitesi 2,05 kW iken R417A'nın 1,42 kW ve R422D'nin soğutma kapasitesini $1,32 \mathrm{~kW}$ olarak tespit etmiştir. COP değerleri de soğutma kapasitesine oranla R22'li sisteme kuyasla düşmektedir. Yani iklimlendirme cihazlarında R422D akışkanını tercih etmenin akıllıca bir seçim olmayacağını belirtmiştir. Tespit ettiği diğer önemli bir husus ise sicaklık artarken R22 ile R417A akışkanlarının COP değerlerinin birbirine oldukça yakınsamasıdır; $41^{\circ} \mathrm{C}$ 'de R417A'nın COP değeri, R22'nin COP değerinden sadece $\% 13,28$ daha azdır $\left(35^{\circ} \mathrm{C}\right.$ iken bu oran $\% 16,23$ değerindedir). $\mathrm{Bu}$ yüzden sicak bölgelerde iklimlendirme/soğutma uygulamaları yaparken R417A soğutucu akışkanının kullanılabileceği sonucuna ulaşmıştır [38].

Soylu (2019), düşük GWP'ye sahip R152a, R1234yf ve R1234ze(E) soğutucu akışkanlarının performansları R134a ile karşılaştırmıştır. Deneysel 1S1 pompası sisteminde farklı soğutucu akışkanlar hem 1sıtma, hem de soğutma modunda test edilmiştir. Aynı zamanda Sıvı hattına yerleştirilen plakalı bir iç 1S1 değiştiricinin, düşük performanslı soğutucu akışkanların sistem performans parametreleri üzerine etkisini incelemiştir. R152a soğutucu akışkanının soğutma COP değeri R134a'nın soğutma COP değerinden $\% 11$ daha fazla olduğundan sistem üzerinde 1sı değiștiricisine ihtiyaç duyulmadığını, iç 1S1 değiştirici sistemde aktif iken R1234yf' de \%5-6 ve R1234ze'de \%4-5 oranında soğutucu akışkanının STK'sında artış meydana geleceğini belirtmiştir. Deneysel 1S1 pompas1 sistemi 1sitma modunda incelendiğinde R152a'nı 1sıtma COP'sinin R134a'dan \%2 oranında daha yüksek, R1234yf ve R1234ze(E) soğutucu akışkanlarının 1sıtma COP değerleri incelendiğinde ise akışkanların ısıtma COP'ları R134a'dan sirasıyla \%4 ve \%11 oranında daha düşük gerçekleştiğini gözlemlemiştir [39].

Aksu (2019), farklı çalışma şartlarında $\mathrm{CO}_{2}$ (R744) soğutucu akışkanlı buhar sıkıştırmalı sudan suya bir 1sı pompasının COP'sini subkritik bölgede deneysel ve teorik olarak incelemiştir. Sudan suya bir 1S1 pompası sistemi tasarlanarak iki farklı duruma göre deneyler gerçekleştirmiștir. Birinci grup deneylerde; evaporatör su debisi $500 \mathrm{lt} / \mathrm{h}$ değerinde sabit tutularak, kondenser ve evaporatör giriş suyu sıcaklıkları $11^{\circ} \mathrm{C}$, $13{ }^{\circ} \mathrm{C}$ ve $15{ }^{\circ} \mathrm{C}$ değerinde değiştirilerek, $600 \mathrm{lt} / \mathrm{h}, 700$ 
lt/h ve $800 \mathrm{lt} / \mathrm{h}$ değerlerindeki farklı kondenser su debilerinin 1S1 pompası performansı üzerindeki etkileri gözlemlenmiştir. İkinci grup deneylerde ise; kondenser su debisi $500 \mathrm{l} / \mathrm{h}$ değerinde sabit tutularak, kondenser ve evaporatör giriș suyu sıcaklıkları $11^{\circ} \mathrm{C}$, $13{ }^{\circ} \mathrm{C}$ ve $15{ }^{\circ} \mathrm{C}$ değerlerinde değiştirilerek $600 \mathrm{lt} / \mathrm{h}$, 700 lt/h ve 800 lt/h değerlerindeki farklı evaporatör su debilerinin 1s1 pompası performansina etkisini gözlemleyerek enerji analizi yapmıştır. Enerji analizi sonuçlarına göre birinci grup deneylerde 1s1 pompasının COP değerinin 3,75 ile 4,049 aralığında, ikinci grup deneylerde ise 3,192 ile 3,75 aralığında değiştiğini görmüştür. Ekserji analizinden elde edilen sonuçlardan, 1sı pompası ekserji veriminin birinci grup deneylerde 0,403 ile 0,428 aralığında, ikinci grup deneylerde ise 0,394 ile 0,416 aralığında değiştiğini belirlemiştir [40].

Arora ve Kaushik (2008), soğutucu akışkan olarak R507A, R502 ve R404A'nın kullanıldığı buhar sıkıştırmalı soğutma çevrimin de evaporatör sıcaklığ 1 $-50^{\circ} \mathrm{C}$ ile $0^{\circ} \mathrm{C}$, kondenser sicaklığ değerleri arasında değişen koşullarda sistemin ekserji analizini yapmışlardır. Sonuç olarak R502 soğutucu akışkana muadil olarak kullanılacak akışkanlardan R507A akışkanının R404A'ya kıyasla verdiği sonuçların daha iyi olduğu gözlemlenmiştir [41].

Niu ve Zhang (2007), R744/R290 soğutucu akışkan karışımının ozon tabakasına zararının dokunmadığını ve çevre dostu olduğunu belirleyerek, R13'e alternatif olabileceğini COP değerinin ve soğutma kapasitesinin daha yüksek olmasından çıkarmıştır, bu çıkarımı çalışmalarında deneysel olarak ortaya koymuşlardır [42].

Okudan (2020), R-410A soğutucu akışkanlı çatı tipi klima sistemlerinde kullanılabilecek GWP değeri düşük alternatif soğutucu akışkanlardan R-452B, R454B ve R-32'nin performans verilerini teorik olarak incelemiştir. R-452B ve R-454B soğutucu akışkanlı sistemlere dönüştürülürken cihaz kapasitelerinde en fazla \%6,55 düşüş yaşandığını, öte yandan R-32 soğutucu akışkanlı sistemde soğutma kapasitesinde $\% 6,67$, ,sıtma kapasitesinde $\% 4,96$ artış sağlandığını tespit etmiştir. Şarj miktarları yönünden baktığında tüm alternatif soğutucu akışkanlarla soğutucu akışkan şarj miktarlarında azalma sağlandığını gözlemlemiştir. R-452B ve R454B soğutucu akışkanlı sistemlerde \%13,53 soğutucu akışkan miktarında azalma elde edilmekle beraber en büyük azalmanın R32 soğutucu akışkanlı sistemde \%19,66 oranında sağlandığını belirtmiştir [43].
Padilla ve arkadaşları (2010), soğutma çevrimlerinde R413A (R134a/R218/R600a \%88/9/3) karışımını R12 soğutucu akışkanına alternatif olarak çalışmalarında sunmuşlardır. Deneysel çalışmalarının sonucunda ekserji veriminin R12'den daha iyi olduğunu ve enerji tüketiminin de daha az olduğunu göstermişlerdir [44].

Fatouh ve Kafafy (2006), \%60 propan ve \%40 ticari bütan içeren LPG kullanarak soğutma sisteminin enerji tüketimini deneysel olarak incelemişlerdir. Deney sonucunda COP değerinin \%7,6 arttığını ve enerji tüketiminin $\% 10,8 \quad$ azaldığını gözlemlemişlerdir. LPG'nin sistem şarjı arttıkça deşarj sıcaklığının, elektrik tüketiminin ve soğutma kapasitesinin artacağını böylelikle LPG şarjının optimum $60 \mathrm{~g}$ olması gerektiğinin tespitini de çalışmalarında yapmışlardır [45].

Kim ve arkadaşları (2004), R32/R134a karışımı akışkanların farklı oranlarda kullanıldığı 1sı pompası sistemini deneysel olarak incelemişlerdir. Deney sonucunda R32 oranının \%13 den \%26 oranına çıkartılması ile soğutma deneyinde kapasite 2,6'dan 3,4'e, 1sitma deneyinde de kapasite 1,8'den 2,4'e yükseldiği gözlemlenmiştir. Ayrıca karışımda R32 soğutucu akışkanının oranının artması sonucunda sistemin soğutma ve 1sıtma kapasitesinde iyileşme olduğunu gözlemlemişlerdir [46].

Jung ve arkadaşları (2000), çok kademeli 1Sı pompas1 sisteminde R32/R125/R134a karışımının R22 soğutucu akışkanlı sistemden \%4-5 daha yüksek COP değerine sahip olduğunu ve R32/R134a karışımının R22'ye göre COP değerinde \%7 artış gözlemlenir iken, R290/R134a azeotropik karışımı kapasite ve COP değerinde \%3-4 artış sağladığını çalışmalarında gözlemlemişlerdir [47].

Rohlin (1996), soğutucu akışkan karışımları belirlenirken yerine geçeceği akışkanın özelliklerine yakın olması gerektiğini, mevcut durumlarda bu durumun çok önemli olduğunu ve karışımlarda HFC akışkanları olan R143a, R125, R152a, R134a, ve R32 saf bileşenleri kullanıldığını belirterek bu akışkanlardan bazılarının az miktar da izobütan ve propan içerdiğini belirtmiştir [48].

Jeon ve arkadaşları (2020) düşük GWP soğutucu akışkanlara sahip yeni ejektör genleşmeli klimaların mevsimsel performans özelliklerini incelemişlerdir. Bir simülasyon modeli kullanılarak, düşük GWP'ye sahip soğutucu akışkan kullanan yeni ejektör genleşmeli klimaların COP değerini, soğutma 
mevsimsel performans faktörü ve yaşam döngüsü iklim performansı çeşitli çalışma koşullarında ve modlarında analiz edilmiştir. R290'lı ejektör genleşmeli klimaların, R410A ile temel klimanınkinden sırasıyla\% 22 daha yüksek soğutma mevsimsel performans faktörü ve \% 23,3 daha düşük toplam $\mathrm{CO}_{2}$ emisyonları sergilemiştir. Genel olarak R290, mevsimsel performans ve ömür boyu çevre faktörü açısından ejektör genleşmeli klimalar için en iyi çalışma sıvısı olduğunu göstermişlerdir [49].

He ve arkadaşları (2020) transkritik $\mathrm{CO}_{2}$ 1sı pompası su 1sitıcisının performansı modelleyerek, optimum yüksek basınç ve soğutucu akışkan şarjı arasındaki ilişkiyi araştırmışlardır. Sistemin optimum şarjı herhangi bir çalışma koşulu altında sabit kalabilirse, sistem sabit soğutucu şarjlı optimum COP' de otomatik olarak çalışacağını gözlemlediler. Değişken çalışma koşulları altında ise optimum şarj değişimini en aza indirerek optimum COP'ye yaklaşmak için sistem tasarım yöntemleri geliştirmişlerdir. Sonuç olarak, 1S1 eşanjörlerini yeniden boyutlandırdıktan sonra sabit şarjlı sistemin ortalama COP kaybının yalnızca $-\%$ 0,8, gaz soğutucunun çıkışındaki yüksek basınçlı bir rezervuarla karşılaştırıldığında, ortalama COP kaybının -\% 0,2 kadar düşük olabileceğini gösterdiler [50].

Opalic ve arkadaşları (2020) genel bir enerji yönetim sistemine yerleştirmek için operasyonel $\mathrm{CO}_{2}$ soğutucu akışkan tabanlı endüstriyel soğutma sistemlerini modellemek için yapay sinir ağı tabanlı bir teknik geliştirmişlerdir. Sunulan model, bireysel kompresör tipi özelliklerini içeren verilerden öğrendiği için genelleştirilmiş bir teorik modelden daha üstündür. Sunulan yaklaşımın, bir vaka çalışması sisteminden düşük çözünürlük ve asenkron veriler kullanılarak, \% 5 kadar düşük bir ortalama yüzde hatası ile nispeten kesin olduğunu göstermişlerdir. Aynı zamanda geliştirilen modeli bir laboratuvar ortamında da test edilmişlerdir ve ortalama yüzde hatasının \% 1,8 kadar düşük olduğunu bulmuşlardır [51].

Wu ve arkadaşları (2020) $100{ }^{\circ} C^{\prime}$ nin üzerinde çıkış sıcaklığına sahip yüksek sıcaklıklı farklı 1Sı pompalarının performansını karşılaştırmak için, altı soğutucu akışkan seçmişlerdir. Doğal soğutucu akışkan olarak R718, HC olarak R600 ve R601, HFO olarak R1234ze ve R1336mzz ve HFC olarak R245fa soğutucu akışkanlarını seçmişlerdir. Simülasyon sonuçlar1, R718'in tüm bu soğutucu akışkanlar arasında en iyi sistem performansina ve Carnot verimliliğine sahip olduğunu gösterdiler. Ardından, endüstriyel işlemede R718 yüksek sıcaklık çıtısının fizibilitesini doğrulamak için bir R718 yüksek sıcaklıklı 1sı pompasının prototipi oluşturdular. R718, R1336mzz, R600 ve R245fa'nin deneysel karşılaştırması, yeni HFO soğutucu R1336mzz, yanıcı HC R600 veya geleneksel yüksek sicaklıklı 1s1 pompasının soğutucu R245fa ile karşılaştırıldığında, R718'in yüksek sicaklıklı 1s1 pompası uygulamalarında benzersiz avantajlarına sahip olduğunu gösterdiler [52].

Massuchetto ve arkadaşları (2019) iki buhar sıkıştırma çevriminden oluşan kademeli bir soğutma sisteminde üç farklı karışım soğutucunun (R744/R1270, R744/R717, R744/RE170) termodinamik performansını değerlendirmişlerdir. Sistemleri, evaporatördeki $100 \mathrm{~kW}$ sabit soğutma hızı dikkate alınarak COP maksimizasyonu için optimize etmişlerdir. Optimizasyondan sonra, saf soğutucu akışkanlar için elde edilen değerlere göre COP' nin $\% 18$ 'den \% 32'ye çıktığını hesaplamışlardır. COP değerinin 2.34, ekserji veriminin \% 30'a kadar artması, soğutucu akışkan kütle akış hızının \%6 ile $\% 34$ aralığında olması, kompresör gücününün \%20 ile $\% 23$ ve ekserji yıkımının \%31-\%36 kadar düşürülmesiyle R744/RE170 karışımı en iyi sonuçları göstermiştir [53].

Duarte ve arkadaşları (2019) küçük bir doğrudan genleşmeli güneş destekli 1sı pompası için soğutucu akışkanlar arasında karşılaştırmalı bir çalışma sunmuşlardır. Soğutucu akışkan olarak R134a'yı referans seçmişler ve doğal soğutucu akışkan olarak R290, R600a, R744 ve R1234yf'yi kullanmışlardır. $\mathrm{R} 290$ 'nın $300 \mathrm{~W} / \mathrm{m}^{2}$ ile $700 \mathrm{~W} / \mathrm{m}^{2}$ arasındaki güneş radyasyonu ve $10{ }^{\circ} \mathrm{C}$ ile $35{ }^{\circ} \mathrm{C}$ arasındaki ortam sıcaklığı için diğer soğutucu akışkanlardan daha iyi COP' ye sahip olduğunu göstermişlerdir. Ayrıca, 50 $\mathrm{W} / \mathrm{m}^{2}$ güneş radyasyonunda $\mathrm{R} 134 \mathrm{a}, \mathrm{R} 290$ 'dan daha iyi COP' ye sahip olduğunu belirtmişlerdir [54].

\section{SONUÇ ve ÖNERILLER (CONCLUSION AND RECOMMENDATIONS)}

Çeşitli özelliklere sahip birçok soğutma ya da 1sıtma amaçlı kullanılabilen akışkanlar mevcuttur. Yaygın olarak kullanılan HCFC, HFC gibi sentetik soğutucu akışkanların yanı sıra propan (R290), etan (R170) gibi hidrokarbon soğutucular ve amonyak (R717), karbon dioksit (R744) gibi doğal soğutucu akışkanlar endüstrinin farklı alanlarında kullanılmaktadır. Enerji sistemlerinde doğal soğutucu akışkanlar kullanılırken sahip olduğu özelliklere göre iyileştirme odaklı çalışmalar yapılması, teknolojik olarak doğal soğutucu akışkanların kullanımını 
arttıracaktır. Böylece doğal soğutucu akışkanların daha fazla kullanımı ile olumsuz çevresel etkiler azaltılacaktır. Yalnızca sistemin maksimum verimliliğini sağlaması seçilen akışkanın doğru ve kullanılabilir olduğu anlamına gelmemeli ve aynı zamanda çevreye zarar vermiyor olması oldukça önemlidir. Böylelikle düşük ODP ve GWP değerine sahip akışkanların önemi artmıştır. İncelenen araştırmalar ve yapılan çalışmaların neticesinde sentetik soğutucu akışkanlara karşı çevreye daha duyarlı olan doğal soğutucu akışkanların önemi ortaya konulmuştur. Günümüz ve gelecek için alternatif soğutucu akışkanlar üzerine daha fazla çalışmaya, sistem ve sistem elemanlarının seçilen akışkan ile uyumlu olması için araştırmaların artmasının bir ihtiyacının olduğu görülmüștür. Bununla beraber zaman içerisinde gelişen teknoloji sayesinde alternatif soğutucu akışkanların uygulamalarda kullanılabilirliğinin arttığını, akışkana yönelik sistem tasarımları ile tatmin edici sonuçların alınabildiğine yapılan çalışma neticesinde ulaşılmıştır.

Soğutma sistemlerinde soğutma gücüne bağlı olarak sistemde kullanılacak soğutucu akışkan miktarı ve bu soğutucu akışkanın bir şekilde doğaya salımı ile doğaya verebileceği zararlar ve etkileri göz önünde bulundurulmalıdır.

Isıtma ve soğutma sistemi tasarımciları sistemde soğutucu akışkan seçimi yaparken, hem COP değeri hem de soğutucu akışkanın çevreye verebileceği zararlar ile seçilen soğutucu akışkan kullanımındaki riskleri dikkate almalıdır.

\section{ÇIKAR ÇATIŞMASI BILDİRIMİ (CONFLICT OF INTEREST STATEMENT)}

Yazarlar tarafından herhangi bir çıkar çatışması bildirilmemiştir.

\section{KAYNAKLAR (REFERENCES)}

[1] I. Garg and V.K. Bajpai, "To study various performance parameter of a vapor compression refrigeration system with two evaporators using R134a", Journal of Basic And Applied Engineering Research, Vol. 5 (4), pp. 268-271, 2018.

[2] M.C. Elvas, I. Peres, S. Carvalho, "Making Science Cooler: Carré's Apparatus", The Circulation of Science and Technology: Proceedings of the 4th International Conference of the Eshs, Barcelona, vol. 441, pp. 18-20, November, 2010.
[3] T. Koyun, A. Koyun and M. Acar, "Soğutma Sistemlerinde Kullanılan Soğutucu Akışkanlar ve Bu Akışkanların Ozon Tabakası Üzerine Etkileri", Tesisat Mühendisliği Dergisi, vol. 88, pp. 46-53, 2005.

[4] M. Aktaş, M. Koşan, E. Arslan and A.D. Tuncer, "Designing a novel solar-assisted heat pump system with modification of a thermal energy storage unit", Proc IMechE Part A: J Power and Energy. Vol. 233(5), pp. 588-603, 2019. doi: $10.1177 / 0957650919847934$

[5] A. Mcculloch, "CFC and Halon Replacements in the Environment," Journal of Fluorine Chemistry, vol. 100 (1-2), pp. 163-173, 1999. doi: 10.1016/S0022-1139(99)00198-0

[6] E. Beşer, "Soğutucu Maddelerle İlgili Dünya'da ve Türkiye'deki Gelişmeler", $W$. Ulusal Tesisat Mühendisliği Kongresi ve Sergisi,TESKON 1997, İzmir,20-23 Kasım 1997,A. Güngör, Z. İlken, A. Hepbaşl1, E. Pelin, Ö. Ertöz, N. Bozokalfa,1997Bildiriler Kitabı,MMO Yayın No:203, Cilt 2,pp. 679-697.

[7] N. Abas, A.R. Kalair, N. Khan, A. Haider, Z. Saleem and M.S. Saleem, "Natural and synthetic refrigerants, global warming: A review". Renewable And Sustainable Energy Reviews, vol. 90, pp. 557569, July 2018. doi: 10.1016/j.rser.2018.03.099

[8] D. Colbourne, K.O. Suen, T.X. Li, I. Vince, A. Vonsild. "General framework for revising class A3 refrigerant charge limits - a discussion" International Journal of Refrigeration, vol. 117, pp. 209-217, September 2020. doi: 10.1016/j.ijrefrig.2020.04.024

[9] K. Harby, "Hydrocarbons and Their Mixtures As Alternatives to Environmental Unfriendly Halogenated Refrigerants: An Updated Overview”, Renewable And Sustainable Energy Reviews, vol. 73, pp. 1247-1264, June 2017. doi:10.1016/j.rser.2017.02.039

[10] R. Yajima, K. Kita, S.Taira, N.Domyo, “R32 as a Solution for Energy Conservation and Low Emission"'Eighth International Refrigeration and Air Conditioning Conference, USA, 25-28 July,2000.Available:https://docs.lib.purdue.edu/iracc/ 509/ [Accessed: 1 Nov. 2020].

[11] E. Arcaklioğlu and A. Erişen A, "Soğutucu Akışkan Karışımlarının Buhar Sıkıştırmalı Soğutma Sisteminde Termodinamik Analizi', PamukkaleÜniversitesi Mühendislik Fakültesi 
Mühendislik Bilimleri Dergisi, Vol.9, pp.153-162, Kasım 2003.

[12] A. Mota-Babiloni, M.M. Joybari, J. NavarroEsbrí, C. Mateu-Royo, A. Barragán-Cervera M. Amat-Albuixecha, Molés, F. "Ultralow-temperature refrigeration systems: Configurations and refrigerants to reduce the environmental impact". International Journal of Refrigeration, vol. 111, pp.147-158, March 2020. doi: 10.1016/j.ijrefrig.2019.11.016

[13] B.O. Bolaji and Z. Huan, “Ozone Depletion and Global Warming: Case For The Use of Natural Refrigerant-A Review". Renewable And Sustainable Energy Reviews, vol.18, pp. 49-54, February 2013. doi: 10.1016/j.rser.2012.10.008

[14] S.B. Riffat, C.F. Afonso, A.C. Oliveira and D.A. Reay, "Natural Refrigerants For Refrigeration and Air-Conditioning Systems". Applied Thermal Engineering, vol. 17(1), pp. 33-42, January 1997. Doi: 10.1016/1359-4311(96)00030-0

[15] E. Dikmen, A.Ş. Şahin, Ö.İ. Deveci and E. Akdağ, "GWP Değeri Düşük Soğutucu Akışkanların Kullanıldığı Kaskad Soğutma Sisteminin Karşılaştırmalı Performans Analizi”, El-Cezerî Journal of Science And Engineering, Vol: 7(1), pp. 338-345, 2020. doi: 10.31202/ecjse.630262

[16] M. Boumaza, "Performances Assessment of Natural Refrigerants As Substitutes To Cfc and Hcfc İn Hot Climate". Int. J. Of Thermal \& Environmental Engineering, vol. 1(2), 125-130, 2010. doi:10.5383/IJTEE.01.02.008

[17] H.M. Kim, J. Pettersen and C.W. Bullard, "Fundamental Process And System Design Issues in $\mathrm{CO}_{2}$ Vapor Compression Systems", Progress in Energy And Combustion Science, vol. 30, pp. 119174, 2004. Doi: 10.1016/j.pecs.2003.09.002

[18] E. Ertaş, "Doğal Soğutkanlarla Güncel Uygulamalar", TESKON 2003,IX. Ulusal Tesisat Mühendisliği Kongresi, İzmir, Mayıs 2009,Bildiriler Kitabı,MMO Yayın No: E/2009/494-1, pp. 846.

[19] H.G. Özcan, H. Günerhan and H. Yaldırak, "Alternatif Soğutkan Karbondioksit ve Otobüs Klimalarında Uygulaması', $\quad$ TESKON 2013,11.Ulusal Tesisat Mühendisliği Kongresi, İzmir, 17-20 Nisan 2013, Bildiriler Kitabı, MMO Yayın No:E/2013/601-1, pp. 695.

[20] A.A. Kharazi and N. Müller, "Comparing Water (R718) to other Refrigerants". Process Industries, 2006. doi: 10.1115/IMECE2006-13341
[21] W. Xi, D. Chaobin, X. Shiming, E. Hihara, "State of the art on the flammability of hydrofluoroolefin (HFO) refrigerants", International Journal of Refrigeration, vol. 108, pp. 209-223, December 2019. doi: 10.1016/j.ijrefrig.2019.08.025

[22] Ö. Kizılkan, “A Comparative Investigation of Natural Refrigerants: A Case Study For Cold Storage Application", SDU International Journal of Technological Science, vol. 7(3) December 2015.

[23] C.S. Choudhari and S.N. Sapali, "Performance Investigation of Natural Refrigerant R290 As A Substitute To R22 in Refrigeration Systems". Energy Procedia, vol. 109, pp. 346-352, 2017. doi: 10.1016/j.egypro.2017.03.084

[24] M. Pitarch, E. Navarro-Peris, J. GonzálvezMaciá and J.M. Corberán, "Evaluation of Different Heat Pump Systems For Sanitary Hot Water Production Using Natural Refrigerants". Applied Energy, vol. 190, pp. 911-919, March 2017. doi: 10.1016/j.apenergy.2016.12.166

[25] S. Erten and K. Uludağ, "Soğutma Sistemlerinde R404a ve R290 Soğutucu Akışkan Kullanımının Termodinamik Analizi: Deneysel Karşılaştırma', VII. Uluslararasl Fen, Mühendislik ve Mimarlı Bilimlerinde Akademik Çalışmalar Sempozyumu,Ankara, Türkiye, 15-17 Kasım, 2019,R. Karapınar, A. Güler, Elazığ: Asos Yayınevi, 2019, pp. 254-267.

[26] S.V. Shaik and T.PA. Babu, "Thermodynamic performance analysis of eco friendly refrigerant mixtures to replace R22 used in air conditioning applications". Energy Procedia, vol. 109, pp. 56 - 63, March 2017. doi: 10.1016/j.egypro.2017.03.049

[27] A. Özyurt, N. Erdönmez, B. Yılmaz, D. Yılmaz M.K. Sevindir and E. Mançuhan, " $\mathrm{CO}_{2} / \mathrm{NH}_{3}$ Kaskad Soğutma Sisteminin Termodinamik Analizi ve Performans Değerlendirmesi', TESKON 2015, 12. Ulusal Tesisat Mühendisliği Kongresi,İmir,8-11 Nisan 2015,Bildiriler Kitabı, MMO Yayın No: E/2015/634-1, 2015. pp. 1101-1110.

[28] H. Cho, "Comparative Study On The Performance And Exergy Efficiency Of Solar Hybrid Heat Pump Using R22 and R744', Energy, vol. 93, pp. 1267-1276, December 2015. doi: 10.1016/j.energy.2015.10.016

[29] A. Nguyen, "Influence of an İnternal Heat Exchanger on the Operation of a $\mathrm{CO}_{2}$ Direct Expansion Ground Source Heat Pump", Energy \& Buildings, vol. 202, pp. 110, November 2019. doi:10.1016/j.enbuild.2019.109343 
[30] A. D., Silva, E. P. B., Filho, A. H. P., Antunes, "Comparison of a R744 Cascade Refrigeration System with R404A and R22 Conventional Systems for Supermarkets", Applied Thermal Engineering, vol. 41, pp. 30-35, August 2012. doi: 10.1016/j.applthermaleng.2011.12.019

[31] O. O., Yolcan “Kütahya Bölgesinde Farklı Soğutucu Akışkan Kullanılan Hava, Toprak Ve Güneş Destekli Toprak Kaynaklı Isı Pompalarının TeknoEkonomik Analizi', Yüksek Lisans Tezi, Dumlupınar Üniversitesi, Kütahya, Türkiye, 2017.

[32] D. Colbourne, T.J. Ritter, “Compatibility of nonmetallic metarials with hydrocarbon refrigerants and lubricant mixtures', IIF - IIR Commission, Purdue University, USA, 2000.

[33] K. Boran, T. Menlik ve H. Alpsoy, "R134a/R152a Soğutucu akışkan karışımlarının performanslarının isi pompasinda deneysel olarak araştırılması', Politeknik Dergisi, vol. 18(4), pp. 251256, 2015. doi: 10.2339/2015.18.4

[34] Y.S. Lee, C.C. Su, "Experimental studies of isobutane (R600a) in domestic refrigeration system', Applied Thermal Engineering, vol. 22, pp. 507-519, April 2002. doi: 10.1016/S1359-4311(01)00106-5

[35] S.Ender, “R404A Soğutucu Akışkanı Kullanan Sistemlerde R442A ve R453A Soğutucu Akışkanları Kullanılarak Sistem Verimlerinin Arttırılması', Yüksek Lisans Tezi, Dicle Üniversitesi Fen Bilimleri Enstitüsü, Makine Mühendisliği Anabilim Dalı,Diyarbakır, Türkiye, 2018.

[36] S.Hocaoğlu, “Sistem Parametrelerinin Hidrokarbon Soğutucu Akışkanlı Isı Pompalı Sistemin Yoğuşma Performansı Üzerine Etkisi’, Yüksek Lisans Tezi, Yıldız Teknik Üniversitesi Fen Bilimleri Enstitüsü, Makine Mühendisliği Anabilim Dalı, İstanbul, Türkiye, 2018.

[37] B.Başaran, “Düşük Gwp'li Soğutucu Akışkanların Isı Pompalı Kurutucularda Deneysel Analizi', Yüksek Lisans Tezi, İstanbul Teknik Üniversitesi, Fen Bilimleri Enstitüsü, Makine Mühendisliği Anabilim Dalı, İstanbul, Türkiye, 2019.

[38] İ.Vural, "R22 İle Çalışan Bir İklimlendirme Sisteminde R417A ile R422D Alternatif Soğutucu Akışkanlarının Kullanılmasının Termodinamik Analizi', Yüksek Lisans Tezi, Dicle Üniversitesi Fen Bilimleri Enstitüsü, Makine Mühendisliği Anabilim Dalı, Diyarbakır, Türkiye, 2019.
[39] E.Soylu, “Otomobil İklimlendirme Sistemleri İçin Farklı Alternatif Soğutucu Akışkanların Performanslarının Değerlendirilmesi', Yüksek Lisans Tezi, Yalova Üniversitesi Fen Bilimleri Enstitüsü, Enerji Sistemleri Mühendisliği Anabilim Dalı, Yalova, Türkiye, 2019.

[40] B.Aksu, "Farklı Çalışma Şartlarında $\mathrm{CO}_{2}$ Soğutucu Akışkanlı Isı Pompası Performansının Deneysel Ve Teorik Olarak İncelenmesi', Doktora Tezi, Karabük Üniversitesi Lisansüstü Eğitim Enstitüsü, Makine Mühendisliği Anabilim Dalı, Karabük, Türkiye, 2019.

[41] A. Arora, and S.C.Kaushik, "Theoretical analysis of a vapour compression refrigeration system with R502, R404A and R507A", International Journal of Refrigeration, vol. 31, pp. 998-1005, 2008. doi: 10.1016/j.ijrefrig.2007.12.015

[42] B. Niu, and Y. Zhang, "Experimentalstudy of the refrigeration cycle performance for the R744/R290 mixtures", International Journal of Refrigeration, vol. 30, pp. 37-42, January 2007. doi: 10.1016/j.ijrefrig.2006.06.002

[43] M.O.Okudan, "Çatı Tipi Klimalarda R-410a Alternatifi Soğutucu Akışkanların Kullanımının Analizi', Yüksek Lisans Tezi, Marmara Üniversitesi Fen Bilimleri Enstitüsü, Makine Mühendisliği Anabilim Dalı, İstanbul, Türkiye, 2020.

[44] M. Padilla, R. Revellin, J. Bonjour, "Exergy analysis of R413A as replacement of R12 in a domestic refrigeration system', Energy Conversion and Management, vol. 51, pp. 2195-2201, November 2010. doi: 10.1016/j.enconman.2010.03.013

[45] M. Fatouh, M. El Kafafy, "Experimental evaluation of a domestic refrigerator working with LPG", Applied Thermal Engineering, vol. 26, pp. 1593-1603, October $2006 . \quad$ doi: 10.1016/j.applthermaleng.2005.11.026

[46] M. Kim, M.S. Kim, and Y. Kim, "Experimental study on the performance of a heat pump system with refrigerant mixtures composition change", Energy, vol. 29, pp. 1053-1068, June 2004. doi: 10.1016/j.energy.2003.12.004

[47] D. Jung, Y. Songand and B. Park, “Performance des Melanges de Frigorigenes Utilizes Pour Remplacer le $\mathrm{HCFC}_{22}$ ", International Journal of Refrigeration, vol. 23, pp. 466-474, September 2000. doi: 10.1016/S0140-7007(99)00066-3 
[48] P. Rohlin, "Zeotropik Refrigerant Mixtures in Systems and in Flow Boiling", $\mathrm{PhD}$ thesis Royal Institute of Technology, Stockholm, Sweden, 1996.

[49] Y. Jeon, S. Kim, S.H. Lee, H.J. Chung, "Seasonal energy performance characteristics of novel ejectorexpansion air conditioners with low-GWP refrigerants", Applied Energy, vol. 278, 115715, November $2020 . \quad$ doi: 10.1016/j.apenergy.2020.115715

[50] Y.J. He, X.Y. Liang, J.C. Cheng, L.L. Shao, C.L. Zhang, "Approaching optimum COP by refrigerant charge management in transcritical $\mathrm{CO}_{2}$ heat pump water heater", International Journal of Refrigeration, vol. 118, pp. 161-172, October 2020. doi: 10.1016/j.ijrefrig.2020.06.011

[51] S.M. Opalic, M. Goodwin, L.J. Jiao, H.K. Nielsen, A.A. Pardinas, A. Hafner, M.L. Kolhe, "ANN modelling of $\mathrm{CO}_{2}$ refrigerant cooling system COP in a smart warehouse", Journal of Cleaner Production, vol. 260, 120887, July 2020. doi: 10.1016/j.jclepro.2020.120887

[52] D. Wu, B. Hu, R.Z. Wang, H. Fan, R. Wang, “The performance comparison of high temperature heat pump among R718 and other refrigerants", Renewable Energy, vol. 154, pp. 715-722, March 2020. doi: 10.1016/j.renene.2020.03.034

[53] L.H.P. Massuchetto, R.B.C. Nascimento, S.M.R. Carvalho, H.V. Araujo, J.V.H. Angelo, "Thermodynamic performance evaluation of a cascade refrigeration system with mixed refrigerants: R744/R1270, R744/R717 and R744/RE170", International Journal of Refrigeration, vol. 106, pp. 201-212, October 2019. doi: 10.1016/j.ijrefrig.2019.07.005

[54] W.M. Duarte, T.F. Paulino, J.J.G. Pabon, S. Sawalha, L. Machado, "Refrigerants selection for a direct expansion solar assisted heat pump for domestic hot water", Solar Energy, vol. 184, pp. 527-538, May 2019. doi: 10.1016/j.solener.2019.04.027

\section{Esra DEMIRCI}

1994 yılında Ankara'da doğdu; ilk ve orta öğrenimini Ankara'da tamamladı. Yenimahalle Anadolu Teknik, Teknik ve Endüstri Meslek Lisesi'nden mezun oldu. 2014 yllında Karabük Üniversitesi Teknoloji Fakültesi Enerji Sistemleri Mühendisliği Bölümü’ne başladı 2015 yılında Karabük Üniversitesi Mühendislik Fakültesi Makine Mühendisliği Bölümü Çift Ana Dal Programı (ÇAP)'na başlayıp 2018 yılında iki lisans bölümünden de mezun oldu. 2018 yılında Karabük Üniversitesi Fen Bilimleri Enstitüsü Enerji Sistemleri Mühendisliği Anabilim Dalı'nda yüksek lisans eğitimine başladı. 2020 yılında Nurdil Teknik Soğutma A.Ş.' de çalışmaya başladı. Esra DEMİRCI halen Nurdil Teknik Soğutma A.Ş.'de Tasarım ve Ürün Geliştirme Uzmanı olarak çalışmaya devam etmektedir.

\section{Mehmet ÖZKAYMAK}

1992 y1lında Selçuk Üniversitesi Mühendislik Fakültesi Makine Mühendisliği Bölümünden mezun olmuştur. Gazi Üniversitesi Teknik Eğitim Fakültesi Makine Eğitimi Bölümde 1993'de araştırma görevlisi olarak çalışmıştır. Yüksek lisans ve doktorasını Gazi Üniversitesi Fen Bilimleri Enstitüsünde tamamladı. 1999 yılında Dr. Öğr. Üyesi olarak Karabük Üniversitesi'nde göreve başladı. 20 yıldır Karabük Üniversitesi'nde çalışmaktadır. 2010 yılında Doçent, 2015 yılında Profesör ünvanını almıştır. 2010 yılından bugüne kadar Enerji Sistemleri Mühendisliği Bölüm Başkanlığı, 2015-2017 yıllarında Mühendislik Fakültesi Dekanlığı görevini yürütmüştür. Yenilenebilir enerji, sanayide enerji verimliliği ve soğutma konularında çalışmaları mevcuttur.

\section{Meltem KOŞAN}

1990 yılında Gaziantep’te doğdu. Lise eğitimini 2008 yılında Osmaniye'de tamamladıktan sonra 2014 yılında Osmaniye Korkutata Üniversitesi Mühendislik Fakültesi Enerji Sistemleri Mühendisliği Bölümü'nden mezun oldu. 2014 yilında Kahramanmaraş Sütçü İmam Üniversitesi'nde araştırma görevlisi olarak işe başladı. 2015 yılında Gazi Üniversitesi Enerji Sistemleri Mühendisliği Bölümü'nde araştırma görevlisi olarak (ÖYP) işe başladı ve aynı zamanda Gazi Üniversitesi Fen Bilimleri Enstitüsü Enerji Sistemleri Mühendisliği Anabilim Dalı'nda yüksek lisansa başladı. 2017 yılında Gazi Üniversitesi Fen Bilimleri Enstitüsü Enerji Sistemleri Mühendisliği Anabilim Dalı'nda yüksek lisans çalışmasını tamamladı. 2017 yılında Gazi Üniversitesi Fen Bilimleri Enstitüsü Enerji Sistemleri Mühendisliği Anabilim Dalı'nda doktora çalışmasını devam ettirmektedir. Güneş Enerjisi, PV teknolojileri, 1sı pompası sistemleri ve termal enerji depolama teknolojileri konularında akademik çalışmalar yapmaktadır.

\section{Ahmet Eren AKKOÇ}

1997 yılında Ankara'da doğdu. Lise eğitimini elektrik-elektronik teknolojisi alanında 2015 yılında 
Ankara'da tamamladıktan sonra 2020 y1lında Gazi Üniversitesi Teknoloji Fakültesi Enerji Sistemleri Mühendisliği Bölümü'nden mezun oldu. Yenilenebilir enerji kaynakları, 1sıtma, soğutma ve havalandırma sistemleri, soğutma teknikleri ve uygulamaları konularında akademik çalışmalar yapmaktadır.

\section{Mustafa AKTAŞ}

1979 yllında Bolu'da doğdu. İlk ve orta öğrenimini Ankara'da tamamladıktan sonra 2000 yilında Gazi Üniversitesi Teknik Eğitim Fakültesi Makine Eğitimi Bölümü’nden mezun oldu. 2001 yllında Gazi Üniversitesi Teknik Eğitim Fakültesi Makine Eğitimi Bölümü’nde araştırma görevlisi olarak göreve başladı. 2003 yilında Gazi Üniversitesi Fen Bilimleri Enstitüsü Makine Eğitimi Anabilim Dalı'nda yüksek lisans çalışmasını ve 2007 yılında Gazi Üniversitesi Fen Bilimleri Enstitüsü Makine Eğitimi Anabilim Dalı'nda doktora çalışmasını tamamladı. 2011 yılında doçent unvanını aldı. Kurutma sistemleri, iklimlendirme, enerji verimliliği, soğutma ve güneş enerjisi konularında akademik çalışmalar yapmaktadır. Halen Gazi Üniversitesi Teknoloji Fakültesi Enerji Sistemleri Mühendisliği Bölümü’nde Profesör Doktor olarak görev yapmaktadır. 